\title{
THE EMPEROR'S NEW CLOTHES OR PROBLEMS WITH INTERREGNUM? DYNAMIC CAPABILITIES - REVIEW OF CONCEPTS
}

\section{NOWE SZATY CESARZA CZY PROBLEMY Z BEZKRÓLEWIEM? ZDOLNOŚCI DYNAMICZNE - PRZEGLĄD KONCEPCJI}

\author{
Jolanta Gorgól
}

Wrocław University of Economics, e-mail: gorgol.jolanta@gmail.com

\begin{abstract}
Summary: The aim of the article is to address the problems of the Dynamic Capabilities Approach (DCV) with regard to polarisation, inconsistencies and tautologies, and to propose a new linguistic solution for the challenges of DCV. Through adopting the definitions of the general terms used in DCV (like capacity, ability and capability) from the English language dictionaries, the author builds the concept of capability activation and organizational dynamics. The linguistic platform presented in the article allows to link different perspectives of publications discussing DC issues. By drawing up a new perspective on the concept of capabilities and organizational dynamism, the article clears the problems with tautologies. When it comes to contribution, this article is the first publication from a series of papers extensively discussing the strategic competitive advantage of organization in the perspective of author's Concept of Organizational Competence Emergence (CEC).
\end{abstract}

Keywords: dynamic capabilities, capability activation, potential of organization, dynamism of organization, linguistic platform, Competence Emergence Concept.
Streszczenie: Celem artykułu jest stawienie czoła problemom koncepcji zdolności dynamicznych, ich polaryzacji, niespójności i tautologii poprzez przygotowanie rozwiązania bazującego na zasadach lingwistycznych. Dzięki zastosowaniu definicji ze słowników języka angielskiego do opisania głównych terminów używanych w podejściu dynamicznym (jak zdolność, talent, potencjał) autorka artykułu buduje koncept aktywacji zdolności organizacyjnych i organizacyjnego dynamizmu. Platforma lingwistyczna zaprezentowana $w$ tekście pozwala powiązać odmienne spojrzenia $z$ dotychczasowych publikacji o zdolnościach dynamicznych. Proponując nową perspektywę koncepcji zdolności dynamicznych i organizacyjnego dynamizmu, koncepcja pomaga dotychczasowym zarzutom. Artykuł jest publikacją wprowadzającą do cyklu opisującego problem strategii organizacji i przewagi konkurencyjnej w ujęciu autorskiej koncepcji powstawania kompetencji organizacyjnych (Competence Emergence Concept).

Słowa kluczowe: zdolności dynamiczne, aktywacja zdolności, potencjał organizacji, dynamizm organizacji, platforma językowa, koncepcja powstawania kompetencji. 


\section{Introduction}

The article addresses the challenge of the dynamic capabilities of Gordon's knot - the polarisation of the approach [Di Stefano, Peteraf, Verona 2009/2010; 2014] reflected in a number or misunderstandings and tautologies [Arend, Bromiley 2009]. Building on the linguistic dictionary definitions of the major terms of organizational management (like capacity, ability and capability) the article proposes a simple platform for theoretically underpinning the wealth of DCV publications. The linguistic discipline leads to explainig the phenomenon of organizational capability and its dynamics. The proposal presented below is the first part of the author's larger Concept of Organizational Competence Emergence. The article consists of two major parts. The first part is a critical review of the Dynamic Capabilities Approach and its genesis. The second part discusses the problem of organizational capability creating the language-based fundament for future discussion about capability outcome, its value and impact on the strategic competitive advantage of an organization.

Despite the great efforts of its creators [Teece; 1994; Teece, Pisano, Shuen, 1997] and the large number of publications trying to fulfil and enrich the approach, the Dynamic Capability View still remains in chaos: the great number of publications 'hang loosely' in the space of strategic management science. It is really a pity that for two decades from the beginning of the 1990s, the approach design has not become consistent and sensible enough to serve as a strong theoretical platform for such an amazing amount of scientific output from other authors. They have been researching and describing the internal activities of organizations creating competitive advantage in growing environmental turbulence and complexity, and every day facing the challenge of the increasing speed of organizational change. This issue seems important for the author of this article because of the research value of the published materials discussing organizational change in the perspective of dynamic capabilities. Reasonable criticism of the Dynamic Capabilities Approach sheds an increasingly negative light on the number of scientific studies and hence eventually may lead to official ignorance of the collected scientific data about organizational change [Arend, Bromiley 2009] - all just because of the "dynamic capability label".

The history of the Dynamic Capabilities Approach reminds one of the Hans Christian Andersen story The emperor's new clothes. The DCV was met with an enthusiastic reception, reflected in millions of citations and large numbers of publications deriving from the modern dynamic approach. The DCs idea appeared like a "new king" for strategic management, explaining the fundaments of the success of companies in the growing turbulence of the external environment, trying to answer "how firms change, sustain and develop competitive advantage and capture value" [Ambrosini, Bowman 2009, p. 30]. Despite its initial success, the problem has appeared from the first publications deriving from DCV which started to specify the phenomenon of dynamic capabilities. The growth of diverging definitions was proportional to the growth of the number of authors and publications, the clothes of the king in Hans Christian Andersen's tale.

The Dynamic Capability Approach was created to answer the fundamental strategic management question concerning how to achieve and sustain competitive advantage in the growing dynamism of the external environment. Teece and his co-authors, Pisano and Shuen [1990a; 1990b; 1994; 1997] have endeavoured to develop a framework which explains how certain firms create wealth and how they build their competitive advantage in regimes of rapid change [Teece, Pisano, Shuen 1997, p. 509]. Due to the considerable criticism of the Dynamic Capabilities Approach, it faces accusations of tautology, mixed use and interpretation of terminology, lack of consistency and congruence, mystery and confusion and not meeting the conditions of a scientific theory [Thomas, Pollock 1999] (in: [Wang \& Ahmed 2007]); Williamson 1990; Kratz, Zając 2001; Newbert 2007] (in: [Bareto 2001; Bareto 2001]).

\section{Genesis and development}

The origin of that approach was, like with RBV and CBV, Penrose's analysis and her Theory of Growth [1959; 2007; Teece 2007]. Penrose stated that a firm's resources are comprised of a bundle of services. A firm can create economic value not simply due to the mere possession of resources, but also based on the effective and innovative management of resources [Penrose 1959; Mahoney 1995 ([in: [Kor, Mahoney 2004]). Following that path, Teece et al., found the sources of the competitive advantage in the distinctive ways of coordinating and combining a firm's processes. These processes are created and shaped by the specific positions of a firm's assets and the firm's path based on evolution (history and experience) [Teece et al. 1997]. According to Teece et al. [1997], the winners in the global marketplace are characterised by time responsiveness and rapid and flexible innovation in product creation, coupled with the capability of management for effective coordination and the internal and external redeployment of competences [Teece et al. 1997]. Why do some companies have a large stock of valuable technological assets and struggle to achieve the sustainable competitive advantage? Because they do not possess the dynamic capabilities- "the firm's ability to integrate, build, and reconfigure internal and external competences to address rapidly changing environments" [Teece at al. 1997, p. 516].

For dynamic capabilities, the strategic issue was the identification of "the foundations upon which distinctive and difficult-to-replicate advantages can be built, maintained, and enhanced", how the organization "achieves new and innovative forms of competitive advantage given path dependencies and market positions" [Leonard-Barton, 1992] (in: [Teece et al. 1997, p. 516]). The competitive advantage of the firms, according to "early" Teece [1997], lies in the firm's managerial and 
organizational processes, which are shaped by VRIN assets position and the inherited firm's evolutionary path. Managerial and organizational processes are routines or patterns of current practice and learning. Their major role is coordination/integration, replication, reconfiguration, cooperation and reconfiguration [Barney 1991; Priem, Butler 2001; Locket et al. 2009]. CBV was the scientific reaction to challenge of a too static RBV.

"Strategic management has always been about matching the internal knowledge and work of the organization to the external challenges posed by its environment" [Drucker 1958] (in: [Dreyer 2002, p. XIII]). However, it is the Dynamic Capabilities Approach that strongly emphasizes the importance of path dependence combined with the learning ability of an organization [Teece 1994; 1997].

Bareto [2010, p. 259] distinguishes six elements within the major theoretical underpinning of the Teece et al. [1997] approach: nature, role, context, creation and development, outcome, as well as heterogeneity, which are elaborated upon below:

1. Categorization of the nature of the concept "ability = capacity" as a special kind of capability, its essential role in strategic management (as an extension to RBV).

2. Specification of the desired role (integration/ coordination, building|reconfiguration of internal and external competences) and the end of that capability, with the significance of rules of routines, path dependency and external competences (evolutionary economics context).
3. Focus on the particular type of context - external, rapidly changing environments (RBV extension) in environmental turbulence with an entrepreneurial perspective [Schumpeter 1934].

4. Stating that dynamic capabilities are built rather than bought, they evolve embedded in organizational processes shaped by firms' asset positions and paths from the past (evolutionary perspective).

5. Emphasis on the heterogeneity of dynamic capability across firms, as a result of the specifics of paths, assets unique positions, distinctive processes (similarity to RBV).

6. Stating that the outcome of dynamic capabilities is sustained competitive advantage (RBV perspective in achieving and sustaining a competitive advantage). Teece et al.'s definition of dynamic capabilities also has evolved. In 1994, Teece and Pisano defined dynamic capabilities as "the subset of the competences and capabilities that allow the firm to create new products and processes and respond to changing market circumstances" [Teece, Pisano 1994, p. 541]. In 1997 Teece, Pisano and Shuen wrote about the "firm's ability to integrate, build, and reconfigure internal and external competences to address rapidly changing environments". Subsequently in 2000 Teece [2000, p. 35] used as a definition the "ability to sense and then seize the opportunities quickly and proficiently". Finally, in 2007 he enlarged the definition of dynamic capabilities by maintaining that it "can be disaggregated into the capacity (a) to sense and shape opportunities and

Table 1. Examples of the definitions of dynamic capability

\begin{tabular}{|c|c|c|}
\hline $\begin{array}{c}\text { Year } \\
\text { of publication }\end{array}$ & Authors & Definition of dynamic capability/ies \\
\hline 1994 & Teece, Pisano & $\begin{array}{l}\text { The subset of the competences and capabilities that allow the firm to create new products and processes and respond to } \\
\text { changing market circumstances }\end{array}$ \\
\hline 1994 & Collis & The capability to develop the capability that innovates faster (or better), and so on \\
\hline 1997 & Helfat & $\begin{array}{l}\text { The subset of competences/capabilities which allows the firm to create new products and processes and respond to } \\
\text { changing market circumstances }\end{array}$ \\
\hline 1997 & $\begin{array}{l}\text { Teece, Pisano, } \\
\text { Shuen }\end{array}$ & $\begin{array}{l}\text { The firm's ability to integrate, build, and reconfigure internal and external competencies to address rapidly changing } \\
\text { environments }\end{array}$ \\
\hline 2000 & $\begin{array}{l}\text { Eisenhardt, } \\
\text { Martin }\end{array}$ & $\begin{array}{l}\text { The firm's processes that use resources- specifically the processes to integrate, reconfigure, gain, and release resources- } \\
\text { to match and even create market change: dynamic capabilities thus are the organizational and strategic routines by } \\
\text { which firms achieve new resource configurations as markets emerge, collide, split, evolve, and die }\end{array}$ \\
\hline 2000 & Teece & The ability to sense and then seize opportunities quickly and proficiently \\
\hline 2001 & Griffith, Harley & $\begin{array}{l}\text { Creation of a difficult-to-imitate combination of resources, including the effective coordination of inter-organisational } \\
\text { relationships, on a global basis that provides a firm with a competitive advantage }\end{array}$ \\
\hline 2002 & Zollo, Winter & $\begin{array}{l}\text { A dynamic capability is a learned and stable pattern of collective activity through which the organization systematically } \\
\text { generates and modifies its operating routines in pursuit of improved effectiveness }\end{array}$ \\
\hline 2002 & Lee et al. & A newer source of competitive advantage through conceptualising how firms are able to cope with environmental changes \\
\hline 2002 & Zahra, George & $\begin{array}{l}\text { Change-oriented capabilities that help firms redeploy and reconfigure their resource base to meet evolving customer } \\
\text { demands and competitor's strategies }\end{array}$ \\
\hline 2003 & Winter & Capabilities that operate to extend, modify or create ordinary capabilities \\
\hline 2006 & $\begin{array}{l}\text { Zahra, Sapienza, } \\
\text { Davidsson }\end{array}$ & $\begin{array}{l}\text { The abilities to reconfigure a firm's resources and routines in the manner envisioned and deemed appropriate by its } \\
\text { principal decision maker(s) }\end{array}$ \\
\hline 2007 & Helfat et al. & The capacity of an organization to purposefully create, extend, or modify its resource base \\
\hline 2007 & Teece & $\begin{array}{l}\text { Dynamic capabilities can be disaggregated into the capacity (a) to sense and shape opportunities and threats, (b) to seize } \\
\text { opportunities, and (c) to maintain competitiveness through enhancing, combining, protecting, and when necessary, } \\
\text { reconfiguring the business enterprise's intangible and tangible assets }\end{array}$ \\
\hline
\end{tabular}

Source: [Bareto 2010, p. 260; Menon 2008, p. 3]. 
threats, (b) to seize opportunities, and (c) to maintain competitiveness through enhancing, combining, protecting, and when necessary, reconfiguring the business enterprise's intangible and tangible assets" [Bareto 2010, p. 260]. As Di Stefano, Peteraf and Verona [2009, p. 17] stated in their analysis of 250 publications discussing the Dynamic Capabilities Approach: "One such issue, and arguably the most critical for the robust development of the field, is how to define dynamic capabilities. Due to the complexity of the construct, this has perhaps sparked the most debate and produced the most confusion. While Teece et al. [1997] first defined the term, their definition has been expanded and refined by subsequent authors. In the process, it has also been modified, producing conflicting understandings regarding critical issues, including the nature of dynamic capabilities and their effect on organizational outcomes [Di Stefano, Peteraf, Verona 2009, pp. 17-18].

Table 1 presents the examples of definitions of dynamic capabilities between 1994 and 2007. DCs were defined as abilities/capacities (e.g. [Helfat et al. 2007; Teece 2000; 2007; Winter 2003; Zahra et al. 2006]), specific and identifiable processes and routines [Eisenhardt, Martin 2000], "regular and predictable behavioural patterns inside the firm" [Nelson, Winter 1982, p. 14] learned and stable patterns of collective activities [Zollo, Winter 2002] or capacity as "ability to perform a task in at least a minimally acceptable manner" but also its repeatability in distinguishing process from a onetime change [Helfat et al. 2007, p. 4; Bareto 2010, p. 260].

\section{Variety of types of capabilities}

Dynamic capabilities may differ in the perspective of their impact on organizational processes. Hence, the most often cited authors organize the dynamic capabilities according to three levels based on the hierarchy of their complexity [Menon 2008]. The fundamental first-level of capabilities includes day to day, basic activities processes capabilities which are defined as functional capabilities [Collis 1994; Andreeva, Chaika, 2006], zero-level capabilities [Winter 2003], underlying subprocesses also known as "how we earn a living now" capabilities [Pavlou, Sawy 2006], or just capabilities [Wang, Ahmed 2007]. The second order capabilities are these more related to the dynamic improvement of processes [Menon 2008] - Amit and Schoemaker's [1993, p. 35] "repeated process or product innovations, manufacturing flexibility, responsiveness to market trends, and short development cycle". Collis [1994] referred to them as capabilities related to dynamics, Winter [2003] defined them as first-level capabilities, Andreeva and Chaika [2006] and Wang and Ahmed [2007] saw them as core capabilities. The third-level covers capabilities enabling the creation of power allowing firms to develop new strategies faster than their respective competitors, thanks to the greater recognition of the hidden value contained within different resources
[Menon 2008]. These capabilities can be defined as creative capabilities [Collis 1994], higher-level capabilities [2003], dynamic capabilities [Andreeva, Chaika 2006], second order capability [Pavlou, Sawy 2006] etc. The examples concerning the hierarchy of DCs, as Menon [2008] suggests, do not only supply a wealth of definitions, but also represent a small sample of using the same terms for describing different entities.

Menon [2008, p. 7], in his attempt to conceptualise the activities in the dynamic capabilities literature pertaining the of core processes proposes the following:

1. Sensing activities: understanding customer needs and market dynamics [Pavlou, Sawy 2006], alertness to environmental information [Teece, Pisano 1994], responding to market intelligence [Amit, Schoemaker 1993], disseminating market information [Kogut, Zander 1996].

2. Learning activities: identifying new solutions [Zott 2003], brainstorming, experimenting, and variation [Pisano 1994; Zott 2003], knowledge brokering [Eisenhardt, Martin 2000], pursuing new initiatives [Van den Bosh et al. 1999], knowledge articulating and codifying [Zander, Kogut 1995], generating new thinking [Henderson, Cockburn 1994], innovative problem solving [Lansiti, Clark 1994], inter-organizational learning [Doz, Shuen 1989; Mody 1990].

3. Reconfiguration: reconfiguring operational competencies which influence competitive advantage [Pavlou, Sawy 2006], innovative redeployment of existing resources [Helfat, Peteraf 2003], evolving intra firm resources through imitation and experimentation [Zott 2003], patching - reconfiguring resources into the right chunks at the right scale to address shifting market opportunities [Eisenhardt, Brown 1999], resource redeployment following horizontal acquisition [Capron, Dussauge, Mitchell 1989], attractive new combination of resources [Galunic, Rodan 1998], combining resources into new combinations [Kogut, Zander 1996], revamping (not destroying) existing operational competencies [Grant 1996], experimentation creating multiple alternatives in decision making [Eisenhardt, Tabrizi 1995], the need for internal and external transformation [Langlois 1994], reconfiguring firm's asset structure [Amit, Schoemaker 1993], architectural innovation [Abernathy, Clare 1986].

4. Coordination and Integration: a pattern of collective activity [Zollo, Winter 2002], distributing and assigning knowledge resources, sharing individual knowledge in the group [Okhuysen, Eisenhardt 2002], capturing synergies among tasks and resources [Eisenhardt, Galunic 2000], appointing the right person to the right unit [Eisenhardt, Brown 1999], integrating strategies during corporate acquisitions [Singh, Zollo 1988], keeping managers informed of collective activities [Brown, Eisenhardt 1997], interrelating diverse inputs to jointly execute a collective activity [Grant 1996], integrating the inputs of 
distinct entities [Dougherty 1992], efficiency of internal coordination and integration [Aoki 1990].

This comes close to Teece's "Orchestration" foundation of dynamic capabilities and business performance stated on sensing, seizing and managing threats/transforming dynamic capabilities [Teece 2013, p. 49] and supplying the information on how broad the topic of DCV is. Menon's [2008] analysis of the core activities in dynamic capabilities literature can be resumed in Arend and Bromiley's [2009, p. 86] words that DCV "offers a rich and relevant base from which to advance our understanding of strategic organizational change", but still cannot be treated as a theory. The great number of publications are defined by Arend and Bromiley [2009] as the "halo effect".

\section{Criticism of the approach: "dynamic capabilities as the emperor's new clothes"?}

The biggest challenge leading to chaos in the Dynamic Capability Approach is vocabulary 'stew'. Reflected in Table 1 is the underestimating of linguistic definitions of major terms (e.g. the ability, capacity, capability and competence) that leads to scientific chaos. As a result, the organizational potential for action is mixed with introduced action (process) and with the results of introduced action (the outcome). What is a source of competitive advantage: the potential for action (capability for action), introduced action (process) or the result of action (impact/change/outcome)? Adopting that perspective we can state that even Teece's definitions presented above describe DCs differently - as competences and capabilities allowing for creation of new products [1994], abilities to create competences [1997], the ability to select right potential [2000] or processual capacity [2007]. In the perspective of the organizational change and creation of company advantage we could critically ask: what is a dynamic capability? Is it an organizational potential for change, a process of changing, or achieved change? The Dynamic Capability Approach has not resolved total challenge yet, despite a number of interesting propositions resolving different aspects of DCV (e.g. the drivetrain of Di Stefano, Peteraf and Verona [2014]). Hence, coming back to Andersen's

Table 2. The inconsistencies of DCV

\begin{tabular}{|c|c|}
\hline Author & "Weak sides" of DCV: \\
\hline Czakon W. [2010] & "Not every change of routines can be treated as dynamic competence" (p. 8) \\
\hline $\begin{array}{l}\text { Thomas, Pollock [1999] } \\
\text { (in: [Wang, Ahmed } \\
\text { 2007]) }\end{array}$ & $\begin{array}{l}\text { "Researchers refer dynamic capabilities to a wide range of resources, processes and capabilities. As a result, the literature } \\
\text { is featured by a mixed use and interpretation of terminologies" (p. 6) }\end{array}$ \\
\hline \multirow[t]{3}{*}{ Wang, Ahmed [2007] } & $\begin{array}{l}\text { "[...] empirical studies to date have primarily addressed firm- or industry-specific processes pertinent to dynamic } \\
\text { capabilities based on case studies. Thus far, research on dynamic capabilities has been conducted on a piecemeal basis } \\
\text { and research findings remain disconnected. It is imperative to synthesise the conceptual debates and the diverse empirical } \\
\text { findings toward a more integrated understanding of dynamic capabilities" (p. 9) }\end{array}$ \\
\hline & $\begin{array}{l}\text { "[...] significant number of empirical studies pertinent to dynamic capabilities do not explicate the concept [...]. Instead, } \\
\text { these studies simply describe how firm evolution occurs over time, most usually illustrated through case studies" (p. 6) }\end{array}$ \\
\hline & $\begin{array}{l}\text { antinomies: dynamic capabilities are structured and persistent [Zollo, Winter 2002] }<=>\text { dynamic capabilities as } \\
\text { emergent and evolving [Rindova, Kotha 2001] }\end{array}$ \\
\hline Williamson [1999] & $\begin{array}{l}\text { Concept of dynamic capabilities is tautologically linked to success and fundamental constructs are not properly } \\
\text { operationalized, too broad definitions, too elastic, lack of operational implications, not sufficient concern for competition }\end{array}$ \\
\hline Winter [2003] & $\begin{array}{l}\text { "mystery and confusion around the concept to its excessive connection to generic formulas for universal effectiveness" } \\
\text { (p. 994) }\end{array}$ \\
\hline Kraatz and Zając [2001] & $\begin{array}{l}\text { "while the concept of dynamic capabilities is appealing, it is a rather vague and elusive one which has thus far proven } \\
\text { largely resistant to observation and measurement" (p. 653) }\end{array}$ \\
\hline $\begin{array}{l}\text { Newbert [2007] } \\
\text { (in [Bareto 2001]) }\end{array}$ & "low level of support for a limited subset of empirical tests employing the dynamic capabilities approach" (p. 258) \\
\hline Bareto [2010] & $\begin{array}{l}\text { A theory "is a statement of relations among concepts within a set of boundary assumptions and constraints (Bacharach, } \\
1989, \text { p. 496). Accordingly, a theory requires the specification of (a) the constructs or variables of interest, (b) congruence, } \\
\text { that is, the set of laws of the relationship among constructs or variables, (c) the boundaries within which the laws of } \\
\text { relationship are expected to operate, and (d) the contingency hypotheses within which the integrity of the system } \\
\text { is maintained but in a markedly different condition [Dubin 1978; Fry, Smith 1987]. Next, drawing on these conditions, } \\
\text { I highlight the important strides made by extant research on dynamic capabilities so far, I show why the approach is not } \\
\text { yet a theory" (p. 264) }\end{array}$ \\
\hline Zahra et al. [2006] & $\begin{array}{l}\text { Tautology, incompatibility of usage of the DCV; Firm characteristics mixed with context in definitions; Contradictions; } \\
\text { Regressive identification of dynamic capabilities in empirical work; Lack of causality in dynamic capabilities development } \\
\text { and utility }\end{array}$ \\
\hline Collis [1994 & Collis proposes infinite regress- capabilities come from capabilities etc., unclear concept and definitions of conditions \\
\hline Salvato [2003] & Missing micro-level theory construct \\
\hline Levinthal, Ocasio [2007] & DCV as a theoretical dead end \\
\hline $\begin{array}{l}\text { Di Stefano, Peteraf, Verona } \\
{[2010 ; 2014]}\end{array}$ & $\begin{array}{l}\text { Problems with dynamic capabilities view polarisation in the major areas from nature of the problem, aims, object, agent, } \\
\text { actions, theoretical roots etc. }\end{array}$ \\
\hline
\end{tabular}

Source: based on: [Arend, Bromiley 2009; Bareto 2010; Czakon 2010; Kraatz; Zając 2001; Newbert 2007; Thomas, Pollock 1999; Wang, Ahmed 2007; Williamson 1999; Winter 2003; Menon 2008; Di Stefano, Peteraf, Verona 2009/2010]. 
story we can say that publications concerning dynamic capabilities recall the enchantment of the emperor's new clothes, however everyone receives and describes a different picture and it is not only the problem with the colour perception (e.g. Table 2). "Researchers refer dynamic capabilities to a wide range of resources, processes and capabilities. As a result, the literature is featured by a mixed use and interpretation of terminologies" [Wang, Ahmed 2007, p. 2], and it is full of antinomies [Rindova, Kotha 2001] (in: [Wang, Ahmed 2007; Arend, Bromiley 2009]) e.g. DCV as structured and persistent [Zollo, Winter 2002] or emergent and evolving [Rindova, Kotha 2001], a direct source of competitive advantage [Teece, Pisano 1994; Teece et al. 1997] or an indirect source of competitive advantage [Eisenhardt, Martin 2000; Zahra et al. 2006] in [Arend, Bromiley 2009]. Kraatz and Zając [2001, p. 653] described Dynamic Capabilities Approach as "vague and elusive" and Winter [2003], signified the mystery and confusion of CDC.

A deep analysis of DCV was made by Arend and Bromiley [2009], who summarised the most important accusations concerning DCV:

1. Lack of a clear explanation of how DCV does provide new value to already existing concepts (absorptive capacity, architectural innovation, intrapreneurship, strategic fit, first-mover advantage, organizational learning and change management discuss the same problems).
2. Missing coherent theoretical foundations (mixing the terms-dynamic capability label for very different, sometimes opposite constructs).

3. Poor empirical support.

4. Foggy practical implications [Arend, Bromiley 2009, p. 75].

Di Stefano, Peteraf and Verona [2009/2010; 2014],

in their publications and analysis of 125 papers concerning Dynamic Capabilities View, reveal the major problem of the DC approach - its polarisation (Table 3 ). This polarisation can be seen in all the major perspectives of dynamic capabilities view:

- $\quad$ perspective of construct - the problems with definitions,

- $\quad$ perspective of its nature - from latent action like ability, capacity, enabling device to constituent elements like processes, routines or patterns,

- $\quad$ perspective of agent - a manager versus an organization,

- $\quad$ perspective of action - action focused on changing the existing or creating the new,

- $\quad$ perspective of object of action - competences/resources versus opportunities,

- $\quad$ perspective of aim - different levels of organizational performance (from improving effectiveness (e.g. best practices) to achieving a competitive advantage (e.g. Teece's strategic impact),

- perspective of theoretical roots - from RVB, Evolutionary Economics, Behavioural Theory,

Table 3. The polarisation problem of Dynamic Capabilities Approach

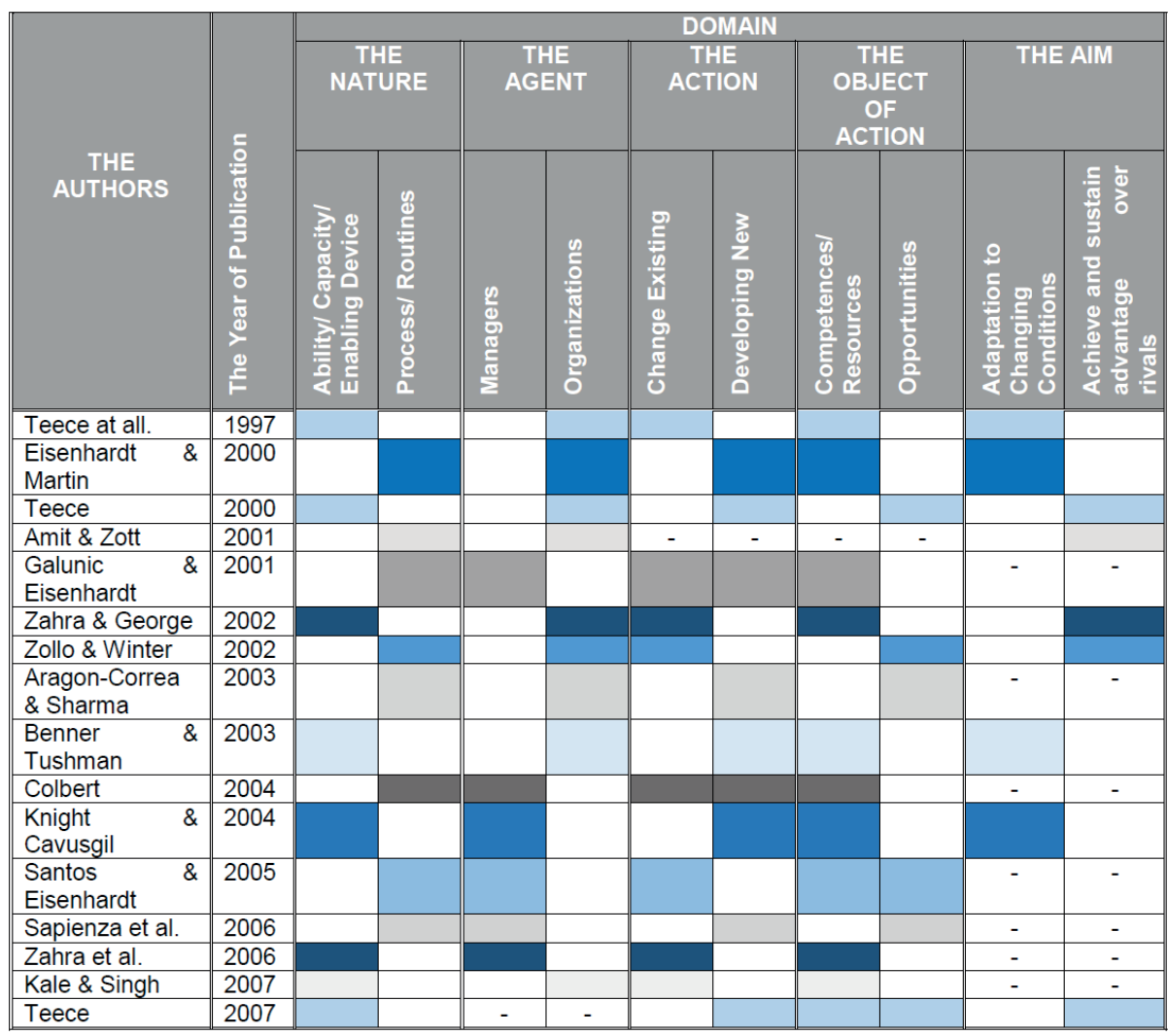

Source: own elaboration based on data from [Di Stefano, Peteraf, Verona 2014, p. 29]. 
Knowledge-based View, Dynamic Resource-Based View).

Table 3 presents the examples of perspectives used by a number of authors discussing a dynamic capability issues. As we can see the same author can change or enlarge its concept (e.g. [Teece et al. 1997] versus [Teece 2000; 2007] or [Zahra, George 2002] versus [Zahra et al. 2006]). That is why a growing number of DCV critics is calling for either clearness in the Dynamic Capability Approach or for abandoning it altogether.

\section{Conclusion and recommendation - a linguistic perspective on organizational capability and dynamics}

Despite the various mentioned problems, the polarisation issue of DCs concept [Di Stefano, Peteraf, Verona 2009/2010; 2014] may be solved in a linguistic way.

Analysing the DCV publications we can state that the biggest challenge that leads to misunderstanding and confusion in the dynamic capability approach is the difference in vocabulary use. It can be stated that a major problem in the DC approach is underestimating the importance of consistent and appropriate linguistic definitions of general terms (like ability, capacity, capability and competence). The problem appears because organizational potential is mixed with the introduced action within the organization (process) and the results of that action. Di Stefano, Peteraf and Verona [2009, p. 19] describe it as a problem with the nature of dynamic capabilities: "whether it is defined in terms of latent action, such as an ability, capacity, or enabling device, or in terms of constituent elements, as in a process, routine, or pattern".

What is a source of competitive advantage: the potential for action (capability for action), introduced action (process) or the result of action (impact/change)? That problem is well reflected in the above mentioned Teece's definitions of DCs, their presentation as competences and capabilities allowing for the creation of new products [1994], abilities to create competences [1997], and the ability to select right potential [2000] or processual capacity [2007]. Discussing the polarisation of DCV [Di Stefano, Peteraf, Verona, 2009/2010] in the perspective of organizational change and company advantage we could critically ask: what is a dynamic capability? Is it an organizational potential for change, a process of changing, or achieved change? Could we say that all DCV publications have a value equals to the emperor's new clothes from Andersen's story? Do the approach criticism and accusations of tautology entitle us to shout that "the emperor is naked!"? If we summarise the huge number of articles concerning organizational activities that have appeared because of the dynamic potential created by Teece at al. [1994; 1997], we have to admit that scientists have collected plenty of fantastic royal clothes, but the real problem of the Dynamic Capability Approach lies in two decades of interregnum - the absence of the 'king' coming from inconsistency of dynamic capability definition. So maybe finally it is time for an election and a ruler who will fit the royal robes? What if we look at DCs publications from the dynamic point of view? If we try to describe how the organizations create potential, utilise it and build competitive advantage based on the linguistic definitions of general terms? What if we try to answer most of the challenges presented by Di Stefano, Peteraf and Verona [2009/2010] and try to elect the ruler?

The Oxford English Dictionary [Murray et al. 1978] distinguishes between ability, capacity and capability: Ability comes from the French 'habilite' (empowers) and can be defined as talent, suitableness, fitness, aptitude, possession of the means or skill to do something. If we analyse the application of the term of ability we can state that is a mainly human characteristic feature [English Living Oxford Dictionaries 2017a]). Capacity means able to take in, that can contain, and it carries a stronger accent on physical aspect of possessing its volume (receive or contain, holding power, content, containing space, area or volume). Capability is defined as a power or ability to do something ${ }^{1}$; a quality of being capable; able to take in, receive, contain, or hold; coming from the Latin: cap-ěre - to take. As a feature it is not confined to humans, it may be organizational [English Living Oxford Dictionaries 2017b].

To create the potential for development, the organization requires necessary assets. As Czakon stated [2009, p. 288]: "Possessing the resources is not the sufficient condition to create the value for the stakeholders. It is the necessity of the skilful use which leads to the competence". Dividing the term capability into two morphemes we can select: cap- and -ability. Hence for the purpose of the understanding the term capability we can assume that organizational capability is a bundle of human and organizational factors - its capacity and ability (Figure 1).

Translating these definitions into strategic management language we could say that: the organizational capability is:

- a potential carried by the organization (e.g. capability (potential) to start the production),

- an organizational quality of being capable of doing something.

These are the following characteristic phenomena accompanying organizational capability: its place and probability of activation (may be), temporality (activity just-in-time) $)^{2}$. If we look at the capability definition from that perspective, we can state that organizational capabilities may appear at every level of organizational activity: from operational to strategic, always involving a human being's

\footnotetext{
${ }^{1}$ Capability $\neq$ ability; capability = ability to do something.

2 Potential - "Having or showing the capacity to develop into something in the future; latent qualities or abilities that may be developed and lead to future success or usefulness, the possibility of something happening or of someone doing something in the future" [English Living Oxford Dictionaries 2017c].
} 


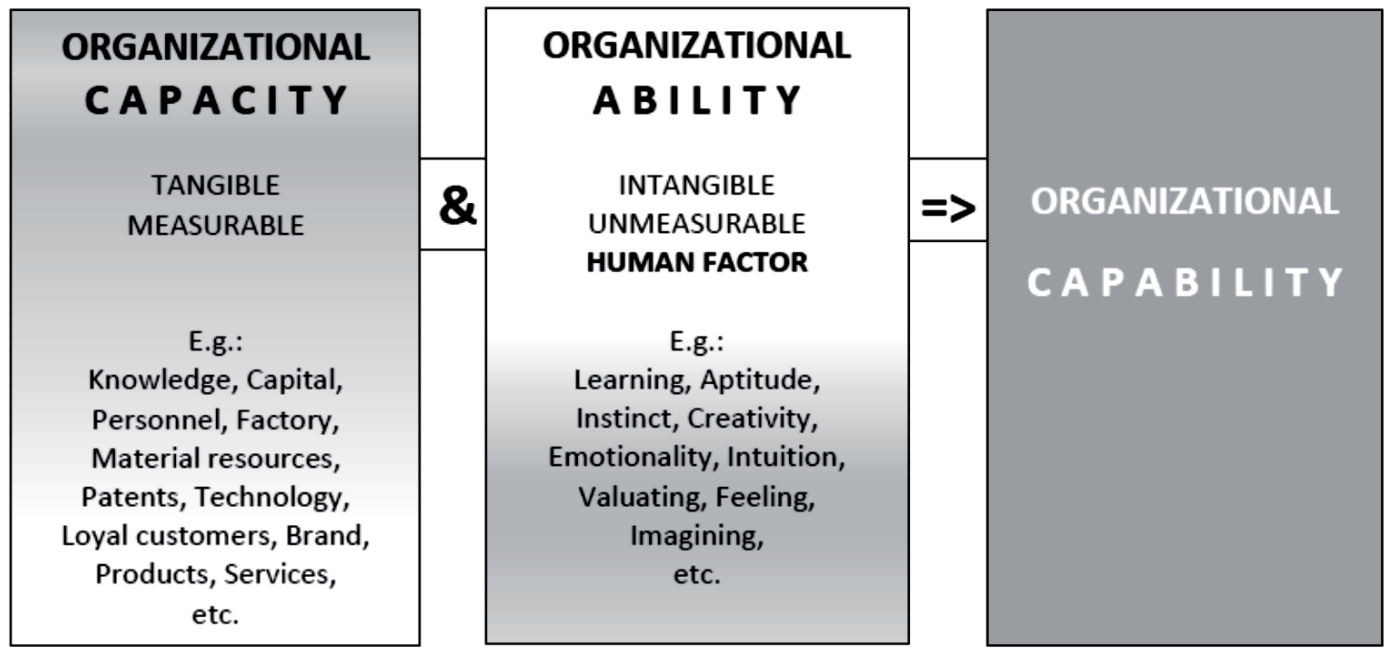

Fig. 1. The organizational capability binding: the particles of organizational capability

Source: own elaboration.

characteristic asset- its personal ability. The potential can be selected at different levels of the organization and its activation may lead to different kind of results: from operational (e.g. increasing efficiency, introducing good manufacturing practice) to strategic (e.g. acquiring the critical strategic asset).

Analysing the dynamism of capabilities, we face the biggest accusation of the approach: a tautology - the assumption that the companies need dynamic capabilities to compete and only companies with dynamic capabilities have a chance to build competitive advantage [Arend, Bromley 2009]. This implies a number of questions: what happens if the company does not possess dynamic capabilities? What are the dynamic capabilities? What does dynamism mean in an organizational and capabilities perspective? Does the DCV discuss the operational dynamic capabilities or strategic dynamic capabilities? Does the dynamism guarantee any strategic advantage? Is an organization without dynamism still a business phenomenon or is just a form registered in the tax system/on paper? Can capability be dynamic?
If we follow the definition that a capability is not a performance, but the potential for performance [Dosi, Nelson, Winter 2000; Dougherty, Barnard, Dune 2004], we should state that the capabilities appear at every level of an organization. Hence, the capabilities approach should be a discussion about organizational potential that is created, actuated and may provide expected outcomes (from operational to strategic). Hence, the problem of dynamics should be discussed as the capabilities' major feature leading to organizational change only in the perspective of the capability activation process and the appearance of its outcome. The organizational potential may be dynamic within its synthesis and induction, which are the stages of a process of capability activation (induction). In other words the capability cannot be dynamic alone, but it can be utilised in a dynamic process.

Organizational potential (capability) may lead to organizational change, and hence at strategic level influence the appearance of competitive advantage, only when it is activated in action (synthesized and induced). Only synthesis and the induction of potential (activation of ca-

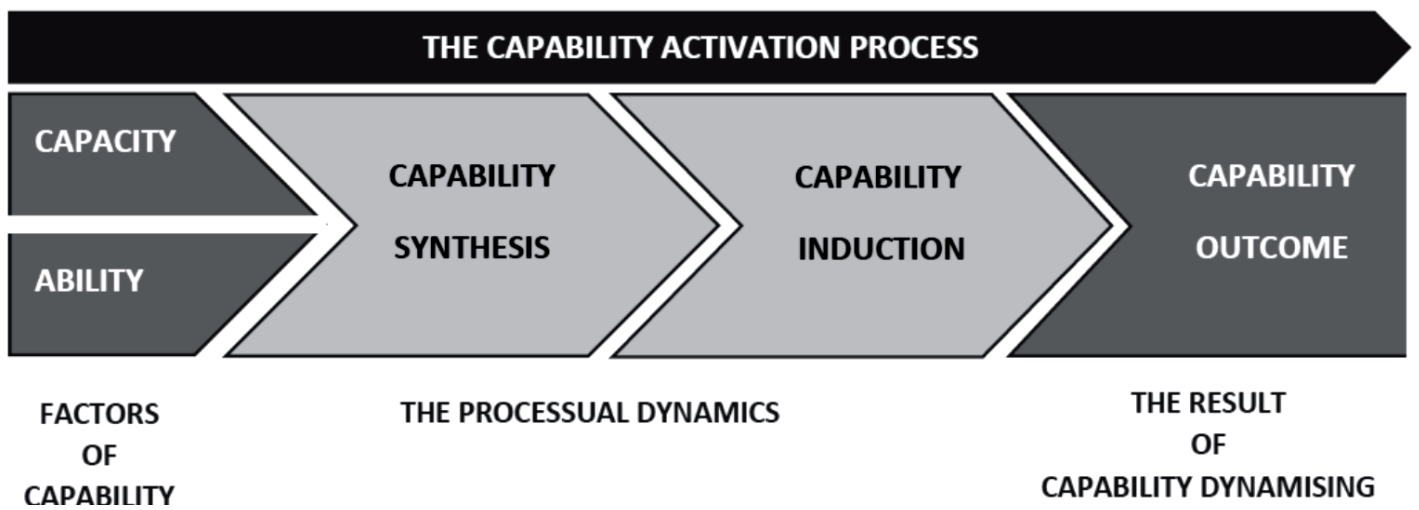

Fig. 2. The potential into action: the capability activation process

Source: own elaboration. 
pability) lead to the results (outcomes of capability activation) (Figure 2). Potential existence cannot provide value, just because it is. To create a valuable outcome it must be activated in the process. Looking from the organizational perspective we can say that dynamic is the process of activation of the capability, not the capability alone.

If we assume that dynamism is an immanent feature of life, that every single life phenomenon realizes itself by processes (even frogs in winter hibernation need slow physiological processes to live) we can state, that a company dies without dynamics - it just does not exist without them. The processual dynamism is the sign of life of the organization. Change is immanent to the existence of an organization and it appears at the level of organizational capability activation process. Change at the strategic level may lead to competitive advantage.

At the end of this discussion we have to answer the question: how does the presented capability activation approach simplify and reduce the challenges of the Dynamic Capability Approach? The answer is presented in Figure 3 - the comparison of polarisation data collected by Di Stefano, Peteraf and Verona [2014] with the linguistic concept. The broader description of the following phenomenon is presented in Table 4.

In summary we can state that by adopting the linguistic approach above we can address the previous challenges of DCs publications by:

1. Explaining the nature of the capability construct as a potential, that can be activated at all levels of organizational activity (through its synthesis and induction).

2. Realising different aims (outcomes) via the potential to change at every level of organizational activity (from operational to strategic).

3. Involving humans in the organizational capability activation process (managers as part of the organization).

The described perspective provides the linguistically based platform for the capability view and its dynamism: it offers the ruler a great number of beautiful clothes publications discussing the area of dynamic capabilities. If we look at the polarisation problem from the viewpoint proposed by the author we can see how the different elements of DCs puzzle fit together (Table 4).

The proposed linguistic platform allows for synthesizing the different aspects of organizational capa-

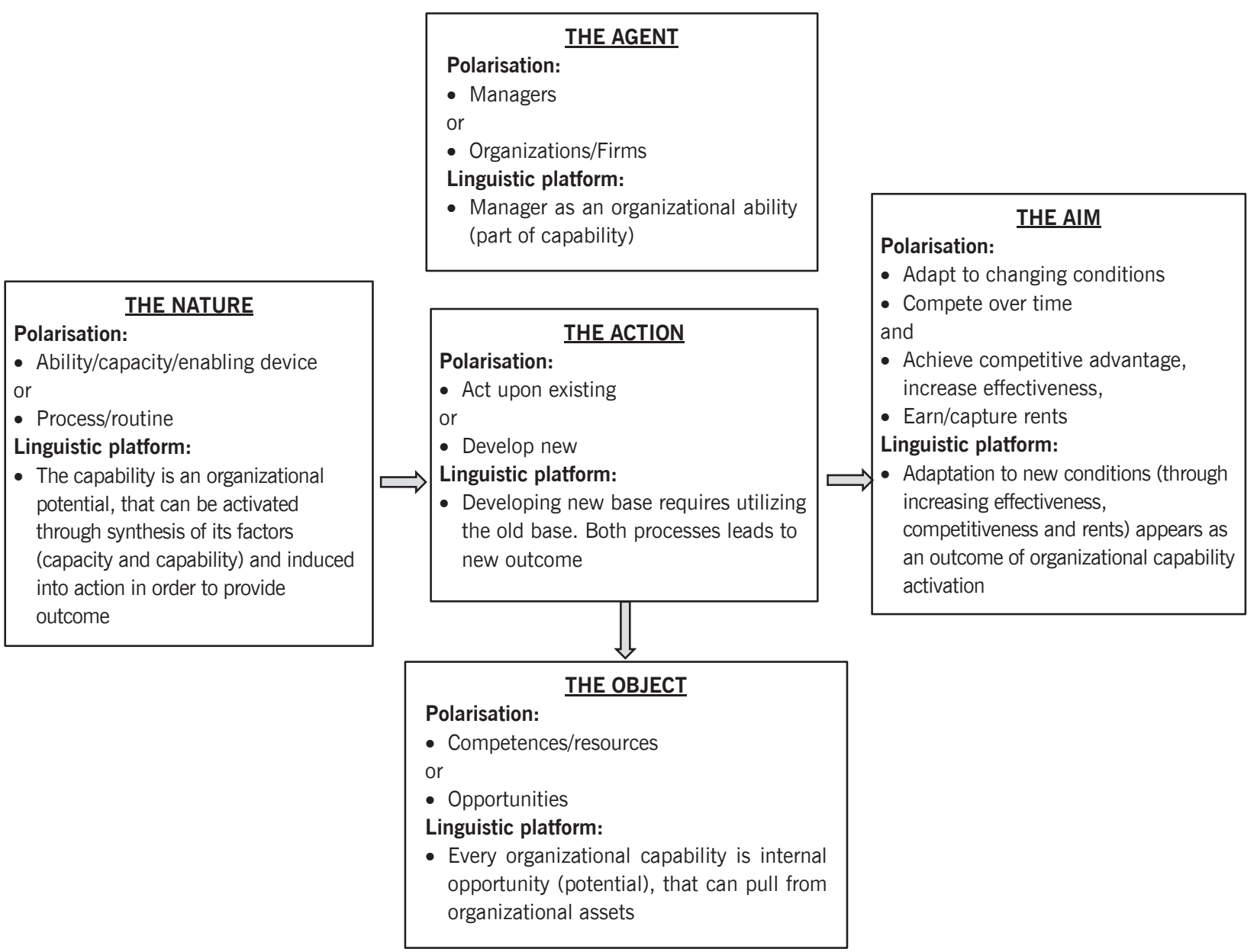

Fig. 3. The concept of linguistic platform in comparison to the polarisation perspective of DCVs

Source: own elaboration adapting the figure of [Di Stefano, Peteraf, Verona 2014, p. 30]. 
Table 4. The Linguistic Platform as solution for Dynamic Capability View polarisation

\begin{tabular}{|c|c|c|}
\hline Domain & $\begin{array}{l}\text { The polarisation of dynamic } \\
\text { capabilities approach }\end{array}$ & Linguistic platform \\
\hline \multirow[t]{2}{*}{ The nature } & $\begin{array}{l}\text { Ability/Capacity/Enabling } \\
\text { Device }\end{array}$ & \multirow[t]{2}{*}{$\begin{array}{l}\text { The organizational capability is a potential that appears as synthesis of managerial ability } \\
\text { and organizational capacity. The capability may be activated and provide outcome. }\end{array}$} \\
\hline & Process/Routine & \\
\hline \multirow[t]{2}{*}{ The agent } & Managers & \multirow[t]{2}{*}{ The manager is a human part of organization (creating ability asset). } \\
\hline & Organizations/Firms & \\
\hline \multirow[t]{2}{*}{ The action } & Change Existing Base & \multirow{2}{*}{$\begin{array}{l}\text { Diverging between changing existing base of resources or developing a new, from capability } \\
\text { activation point of view, is only important when we adopt the external to organization } \\
\text { resources. We should keep in mind that even process of developing new base requires the } \\
\text { utility of existing base. Using other words: even to create the new potential we need to use } \\
\text { existing organizational potential. }\end{array}$} \\
\hline & Developing New Base & \\
\hline \multirow{2}{*}{$\begin{array}{l}\text { The object } \\
\text { of the action }\end{array}$} & Competences/Resources & \multirow{2}{*}{$\begin{array}{l}\text { The organizational capabilities are the potential (opportunities), that may be activated } \\
\text { thanks to synthesis of the organizational assets (capacity and ability). }\end{array}$} \\
\hline & Opportunities & \\
\hline \multirow[t]{2}{*}{ The aim } & Adapt to changing conditions & \multirow{2}{*}{$\begin{array}{l}\text { Creation of advantage over market rivals can be treated as an example of the company's } \\
\text { adaptation to the environmental (internal or external) changes. The capabilities may be } \\
\text { synthesized and induced at every level of organizational dynamics and hence they provide } \\
\text { different outcomes (e.g. adaptation, competitive advantage or both). }\end{array}$} \\
\hline & $\begin{array}{l}\text { Achieve an advantage over market } \\
\text { rivals }\end{array}$ & \\
\hline
\end{tabular}

Source: own elaboration.

bilities and organizational changes (dynamics). It creates the fundament for further discussion concerning organizational capability and organizational learning, the capability outcome value and its influence not only on organizational effectiveness, but also strategic advantage. A number of points concerning synthesizing and utilising organizational potential may be developed in that perspective and will be presented in following papers.

\section{Literature}

Aaoki M., 1990, The Participatory Generation of Information Rents and the Theory of the Firm, [in:] Aaoki M. et al., The Firm as a Nexus of Treaties, London: Sage, pp. 166-83, [in:] Menon A.G., 2008, Towards a Theory of "Dynamic Capability" for Firms, $6^{\text {th }}$ AIMS International Conference on Management, 20-31 Dec.

Abernathy W.J., Clark K.B., 1985, Innovation: Mapping the winds of creative destruction, Research Policy, vol. 14, no. 1, pp. 3-22.

Ambrosini V., Bowman C., 2009, What are dynamic capabilities and are they a useful construct in strategic management?, International Journal of Management Reviews, vol. 11, no. 1, pp. 29-49.

Amit R., Schoemaker P.J.H., 1993, Strategic assets and organizational rent, Strategic Management Journal, 14, pp. 33-46.

Andreeva T., Chaika V., 2006, Dynamic capabilities: What they need to be dynamic?, Discussion paper, Institute of Management no. 10(E), St. Petersburg State University, http://www. academia.edu/1305038/Dynamic_capabilities_What_they_ need_to_be_dynamic, 18.02.2014.

Arend R.J., Bromiley P., 2009, Assessing the dynamic capabilities view: Spare change, everyone?, Strategic Organization, vol. 7, no. 1 , pp. 75-90.

Bacharach S B., 1989, Organizational theories: Some criteria for evaluation, Academy of Management Journal, vol. 43, pp. 837-853.

Bareto I., 2010, Dynamic capabilities: A review of past research and an agenda for the future, Journal of Management, vol. 36 , no. 1 , pp. 256-280.

Barney J., 1991, Firm Resources and sustained competitive advantage, Journal of Management, vol. 17, no. 1, pp. 99-120.
Brown S.L., Eisenhardt K.M., 1997, The art of continuous change: Linking complexity theory and time-paced evolution in relentlessly shifting organizations, Admini-strative Science Quarterly, vol. 42, no. 1, pp. 1-34.

Capron L., Dussauge P., Mitchell W., 1998, Resource redeployment following horizontal acquisitions in Europe and North America, 1988-1992, Strategic Management Journal, vol. 19, no. 7, pp. 631-661.

Collis, D.J., Research note: How valuable are organizational capabilities?, Strategic Management Journal, vol. 15, pp. 143-152.

Czakon W., 2010, Dynamiczne podejście do zarządzania, Acta Universitas Lodziensis, Folia Oeconomica 234, Wydawnictwo Uniwersytetu Łódzkiego, pp. 3-12.

Di Stefano G., Peteraf M., Verona G., 2010, Dynamic capabilities deconstructed, bibliographic investigation into origins, deve/opment, and future directions of the research domain, Industrial and Corporate Change, vol. 19, no. 4, August, pp. 1187-1204, electronic version (2009) accessed on 12.01.2017.

Di Stefano G., Peteraf M., Verona G., 2014, The organizational drivetrain: A road to Integration of dynamic capabilities research, Academy of Management Executive, vol. 28, no. 4, pp. 1-35, https://www.researchgate.net/publication/260287768_The Organizational_Drivetrain_A_Road_To_Integration_Of_Dynamic_Capabilities_Research.

Dosi G., Nelson R.R., Winter S.G., 2000, The Nature and Dynamics of Organizational Capabilities, Oxford University Press, Oxford.

Dougherty D., 1992, Interpretive barriers to successful product innovation in large firms, Organization Science, vol. 3, pp. 179$-202$.

Dougherty D., Barnard H., Dunne D., 2004, Exploring the Everyday Dynamics of Dynamic Capabilities, $3^{\text {rd }}$ Annual MIT/UCI Knowledge and Organizations Conference, Laguna Beach, CA, March 5-7, Center for Research on Information Technology and Organizations, University of California, Irvine.

Doz Y., Shuen A., 1988, From intent to outcome: A process framework for partnerships, Working Paper, INSEAD, Fontainebleau, [in:] Menon A.G., 2008, Towards a Theory of "Dynamic Capability" for Firms, $6^{\text {th }}$ AIMS International Conference on Management, 20-31 Dec.

Dreyer A., 2002, Strategic Management and Core Competencies, Theory and Application, Quorum Books, Westport, Connecticut. 
Drucker P.F., 1985, The Practice of Innovation, Innovation and Entrepreneurship Practice and Principles, Harper \& Raw, New York.

Dubin R., 1978, Theory Building, Free Press, New York.

Eisenhardt K.M., Brown S.L., 1999, Patching: Restitching business portfolios in dynamic markets, Harvard Business Review, vol. 77, no. 3, pp. 72-82.

Eisenhardt K.M., Galunic D.C., 2000, Coevolving: At Last a Way to Make Synergies Work, Harvard Business review, vol. 78, no. 1, pp. 91-110.

Eisenhardt K.M., Martin J.A., 2000, Dynamic capabilities: What are they?, Strategic Management Journal, vol. 21, pp. 1105$-1121$.

Eisenhardt K.M., Tabrizi B.N., 1995, Accelerating adaptive processes: Product innovation in the global computer industry, Administrative Science Quarterly, vol. 40, no. 1, pp. 84-110.

English Living Oxford Dictionaries, 2017a, Oxford University Press, accessed on 5.01.2017, https://en.oxforddictionaries.com/ definition/ability, 5.10.2016.

English Living Oxford Dictionaries, 2017b, Oxford University Press, accessed on 5.01.2016, https://en.oxforddictionaries.com/ definition/capability, 6.02.2017.

English Living Oxford Dictionaries, 2017c, Oxford University Press, accessed on 5.01.2017, https:/en.oxforddictionaries.com/definition/potential, 5.11.2016.

Fry L.W., Smith D.A., 1987, Congruence, contingency, and theory building, Academy of Management Review, vol. 12, pp. 117$-132$.

Galunic D.C., Rodan S., 1998, Resource recombinations in the firm: Knowledge structures and the potential for Schumpeterian innovation, Strategic Management Journal, vol. 19, pp. 1193$-1201$.

Griffith D.A., Harvey M.G., 2001, A Resource Perspective of Global Dynamic Capabilities, journal of international business studies, vol. 32, no. 3, pp. 597-606.

Helfat C.E., Finkelstein S., Mitchell W., Peteraf M.A., Singh H., Teece D.J., Winter S.G., 2007, Dynamic Capabilities: Understanding Strategic Change in Organizations, Blackwell, Malden, Ma.

Henderson R., Cockburn I., 1994, Measuring competence? Exploring Firm effects in pharmaceutical research, Strategic Management Journal, vol. 42, no. 1, pp. 63-84., pp. 1-25.

Iansiti M., Clark K., 1994, Integration and dynamic capability: Evidence from product development in automobiles and mainframe computers, Industrial and Corporate Change, vol. 3, pp. 557-605.

Kogut B., Zander U., 1996, What firms do? Coordination, Identity and Learning, Organization Science, vol. 7, pp. 502-518.

Kory Y.Y., Mahoney J.T., 2004, Edith Penrose's (1959) contributions to the resource-based view of strategic management, Journal of Management Studies, 41: 1, pp. 183-191.

Kraatz M.S., Zajac E.J., 2001, How organizational resources affect strategic change and performance in turbulent environments: Theory and evidence, Organization Science, vol. 12, pp. 632-657, [in:] Bareto I., 2010, Dynamic capabilities: A review of past research and an agenda for the future, Journal of Management, pp. 256-280.

Langlois R., 1994, Cognition and Capabilities: Opportunities Seized and Missed in the History of the Computer Industry, Working Paper, University of Connecticut.

Lee J., Lee K., Rho S., 2002, An evolutionary perspective on strategic group emergence: A genetic algorithm-based model, Strategic Management Journal, vol. 23, no. 8, pp. 727-747.

Leonard-Barton D., 1995, Core capabilities and core rigidities: A paradox in managing new product development, Strategic
Management Journal, summer special issue, vol. 13, pp. 111-125 .

Levinthal D., Ocasio W.C., 2007, Dynamic Capabilities and Adaptation, DRIUD Debates, (Video), 20 June, http://www.druid. dk/streaming/ds2007/onsdag/msh.htm, [in:] Arend R.J., Bromiley P., 2009, Assessing the dynamic capabilities view: Spare change, everyone?, Strategic Organization, vol. 7, no. 1, pp. 75-90.

Locke A., Thompson S., Morgenstern U., 2009, The development of the resources-based view of the firm: A critical appraisal, International Journal of Management Reviews, vol. 11 (1), pp. 9-28.

Mahoney J.T. , 1995, The management of resources and the resource of management, Journal of Business Research, vol. 33, no. 4, pp. 623-632.

Menon A.G., 2008, Towards a Theory of "Dynamic Capability" for Firms, $6^{\text {th }}$ AIMS International Conference on Management, 20-31 Dec.

Mody A., 1990, Learning Through Alliances, Working Paper, World Bank, Washington DC, [in:] Menon A.G., 2008, Towards a Theory of "Dynamic Capability" for Firms, $6^{\text {th }}$ AIMS International Conference on Management, 20-31 Dec.

Murray J., Bradley H., Craigie W.A., Onions C.T., 1978, Oxford English Dictionary, Being a corrected reissue with an introduction, supplement, and bibliography or A new English Dictionary on Historical Principles founded mainly on the materials collected by the Philological Society, Oxford at the Clarendon Press, vol. 1-12.

Nelson R.R., Winter S.G., 1982, An Evolutionary Theory of Economic Change, Cambridge, MA, Harvard University Press.

Newbert S.L., 2007, Empirical research on the resource-based view of the firm: An assessment and suggestions for future research, Strategic Management Journal, vol. 209, pp. 121-146, [in:] Bareto I., 2010, Dynamic capabilities: A review of past research and an agenda for the future, Journal of Management, pp. 256-280.

Okhuysen G.A., Eisenhardt K.M., 2002, Integrating knowledge in groups: How simple forma interventions enable flexibility, Organization Science, vol. 13, pp. 370-386.

Pavlou P.A., El Sawy O. A., 2006, Decomposing and Leveraging Dynamic Capabilities, Working Paper, Anderson Graduate School of Management, University of California, Riverside.

Penrose E., Pitelis C., 1957-2009, The Theory of the Growth of the Firm, with a New Introduction by Christos Pitelis, $4^{\text {th }}$ ed., Oxford University Press.

Priem R., Butler J., 2001, Is the Resource-Based "View" a Useful Perspective for Strategic Management Research?, Academy of Management Review, vol. 26 (1), pp. 22-40.

Rindova V.P., Kotha, 2001, Continuous "Morphing": Competing through dynamic capabilities, form, and function, Academy of Management Journal, vol. 44, no. 6, pp. 1263-1280.

Salvato C., 2003, The role of micro-strategies in the engineering of firm evolution, Journal of Management Studies, vol. 40, no. 1 , pp. 83-108.

Schumpeter J.A., 1934 - 2004, The Theory of Economic Development: An Inquiry into Profits, Capital, Credit, Interest and the Business, $10^{\text {th }}$ ed., Transaction Publishers, New Brunswick, New Jersey

Singh H., Zollo M., 1998, The Impact of Knowledge Codification, Experience Trajectories and Integration Strategies on the Performance of Corporate Acquisitions, Paper Presented at the annual meeting of the Academy of Management, San Diego, California.

Teece D.J., 2000, Strategies for managing knowledge assets: The role of firm structure and industrial context, Long Range Planning, vol. 33, pp. 35-54. 
Teece D.J., 2013, Dynamic Capabilities \& Strategic Management. Organizing for Innovation and Growth, Oxford University Press, Oxford.

Teece D., Pisano G., 1994, The dynamic capabilities of firms: An Introduction, Industrial and Corporate Change, vol. 3, no. 3, Oxford Journals.

Teece D.J., Pisano G., Shuen A., 1990a, Enterprise Capabilities, Resources and the Concept of Strategy, Consortium on Competitiveness and Cooperation, Working Paper CCC, 90-8, Institute of Management Innovation and Organization, University of California, Berkeley.

Teece D.J., Pisano G., Shuen A., 1990b, Firm Capabilities, Resources and the Concepts of Strategy, Economic Analysis and Policy Working Paper EAP-38.

Teece D.J., Pisano G., Shuen A., 1997, Dynamic capabilities and strategic management, Strategic Management Journal, vol. 18 , no. 7 , pp. 509-533.

Thomas H., Pollock T., 1999, From I-O economics' S-C-P paradigm through strategic groups to competence-based competition: Reflections on the puzzle of competitive strategy, British Journal of Management, vol. 10, pp. 127-140, [in:] Wang C.L., Ahmed P.K., 2007, Dynamic capabilities: A review and research agenda, The International Journal of Management Reviews, vol. 9 (1), pp. 31-51.

Van den Bosch F., Volberda H., De Boer M., 1999, Coevolution of firm absorptive capacity and knowledge environment: Organi- zational Forms and combinative capabilities, Organizational Science, vol. 10, pp. 551-568.

Wang C.L., Ahmed P.K., 2007, Dynamic capabilities: A review and research agenda, The International Journal of Management Reviews, vol. 9, no. 1, pp. 31-51.

Williamson O.E., 1999, Strategy research: Governance and competence perspectives, Strategic Management Journal, vol. 20, pp. 1087-1108, [in:] Bareto I., 2010, Dynamic capabilities: A review of past research and an agenda for the future, Journal of Management, pp. 256-280.

Winter S.G., 2003, Understanding dynamic capabilities, Strategic Management Journal, vol. 24, no. 10, pp. 991-995.

Zahra S., George G., 2002, Absorptive capacity: A review, reconceptualization and extension, Academy of Management Review, vol. 27, no. 2, pp. 213-240.

Zahra S.A., Sapienza H. J., Davidsson P., 2006, Entrepreneurship and dynamic capabilities: A review, model and research agenda, Journal of Management Studies, vol. 43, no. 4, pp. 917 $-955$.

Zollo M., Winter S., 2002, Deliberate learning and the evolution of dynamic capabilities, Organization Science, vol. 13, pp. 339$-351$

Zott C., 2003, Dynamic capabilities and the emergence of intra-industry differential firm performance: Insights from a simulation study, Strategic Management Journal, vol. 24, no. 1 pp. 97-125. 